\title{
Xanthogranulomatous pyelonephritis presenting as palmoplantar keratoderma
}

\author{
Joana Caetano, ${ }^{1}$ Marisa Fernandes das Neves, ${ }^{1,2}$ Susana Oliveira, ${ }^{1}$ \\ José Delgado Alves ${ }^{2,3}$
}

'Department of Medicine 4, Fernando Fonseca Hospital, Amadora, Portugal ${ }^{2}$ CEDOC - Center for Chronic Diseases of NOVA Medical School, Lisbon, Portugal ${ }^{3}$ Fernando Fonseca Hospital, Amadora, Portugal

\section{Correspondence to}

Professor José Delgado Alves, jose.alves@fcm.unl.pt

Accepted 28 November 2014

\section{DESCRIPTION}

A 60-year-old woman with type 1 diabetes mellitus and a history of repeated urinary tract infections due to Proteus mirabillis presented with diffuse palmoplantar hyperkeratosis of 4 months duration (figure 1) and acute retrosternal pain. An ECG showed a diffuse concave ST segmental elevation and the echocardiogram showed a mild pericardial effusion, suggestive of pericarditis. Laboratory analysis showed negative troponin, leucocytosis, elevated erythrocyte sedimentation rate $(110 \mathrm{~mm} / \mathrm{h})$ and $\mathrm{C}$ reactive protein $(10 \mathrm{mg} / \mathrm{dL})$. A CT scan

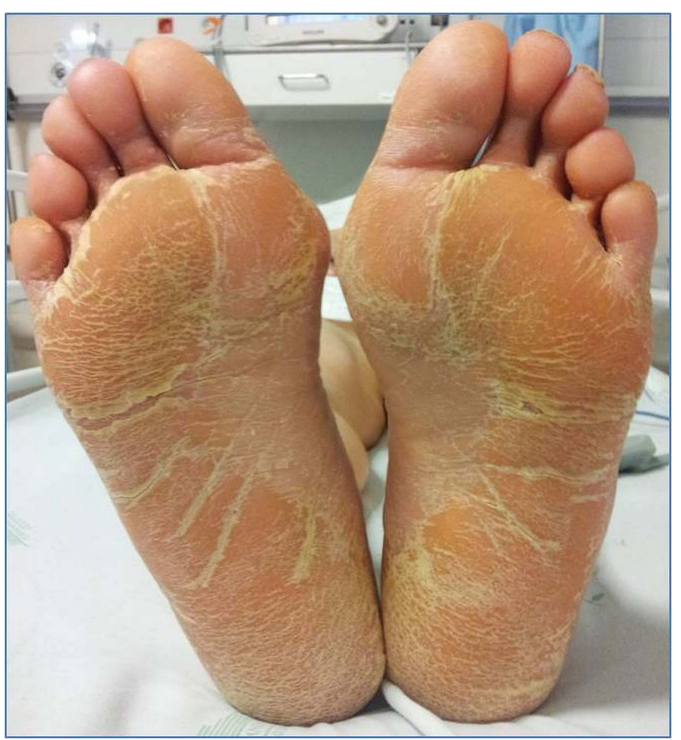

Figure 1 Symmetric, diffuse and yellowish hyperkeratosis of the plantar surfaces, compatible with diffuse plantar keratoderma. revealed a hydronephrotic, non-functioning left kidney with an inflammatory infiltrate in the perinephric fat and a bilateral coraliform calculus. A left radical nephrectomy was performed and the histological diagnosis of xantogranulomatous pyelonephritis was confirmed (figure 2A, B). Complete clinical remission of the cutaneous lesions and pericarditis was observed 1 month after surgery.

Palmoplantar keratoderma is characterised by abnormal thickening of the skin on the palms and soles. It can be hereditary or acquired; when acquired it is associated with malignancy, drugs, infections and chronic systemic diseases, but it can also be idiopathic. ${ }^{1}$

Xanthogranulomatous pyelonephritis is an uncommon chronic destructive inflammatory disease of the renal parenchyma. Most cases occur in the setting of obstruction due to infected renal stones, mostly by Escherichia coli and P. mirabillis. ${ }^{2}$

To the best of our knowledge, this is the first case reported of acquired palmoplantar keratoderma associated with xanthogranulomatous pyelonephritis.

\section{Learning points}

- Acquired palmoplantar keratoderma is a multiaetiological disorder and may be the first manifestation of a systemic disease.

- Recognition of the underlying cause is essential for successful treatment.

- Although very rare, xanthogranulomatous pyelonephritis should be considered in the differential diagnosis of palmoplantar keratoderma.
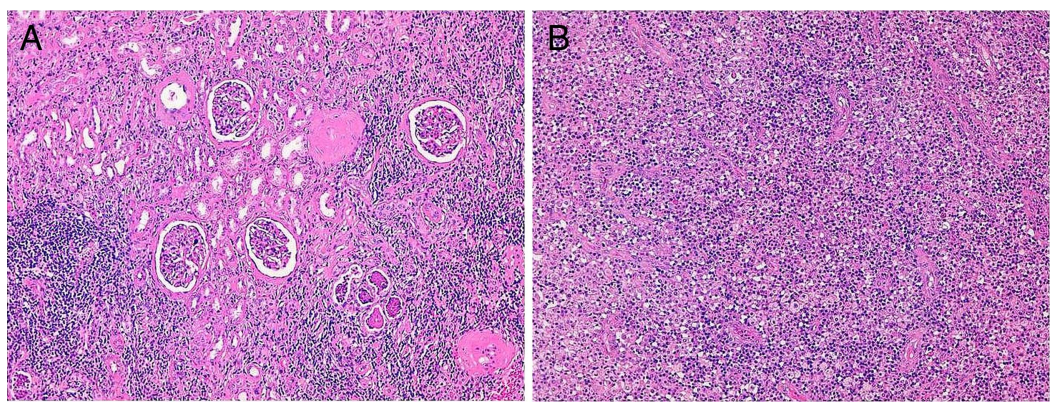

Figure 2 (A) The renal cortex shows some globally sclerotic glomeruli interspaced with others with periglomerular fibrosis, but otherwise relatively preserved. The interstitium is severely compromised by an intense inflammatory infiltrate, with abscess foci and areas of necrosis. There is severe tubular atrophy with peritubular fibrosis (H\&E, $\times 100)$; (B) Renal medulla with a diffuse inflammatory infiltrate, which includes large numbers of foamy histiocytes (lipid-laden macrophages). Some areas of necrosis can also be seen $(H \& E, \times 100)$. 
Acknowledgements The authors thank Dr Sílvia Coelho for her contribution to this article.

Contributors JC and MFN participated in drafting of the manuscript. JDA and SO revised it critically for important intellectual content. All the authors contributed to conception of the work and acquisition of data. All authors approved the final version to be published.

Competing interests None.

Patient consent Obtained.
Provenance and peer review Not commissioned; externally peer reviewed.

\section{REFERENCES}

1 Patel S, Zirways M, English JC III. Acquired palmoplantar keratoderma. Am J Clin Derma 2007:8:1-11.

2 Li L, Parwani AV. Xanthogranulomatous pyelonephritis. Arch Pathol Lab Med 2011;135:671-4.

Copyright 2014 BMJ Publishing Group. All rights reserved. For permission to reuse any of this content visit http://group.bmj.com/group/rights-licensing/permissions.

BMJ Case Report Fellows may re-use this article for personal use and teaching without any further permission.

Become a Fellow of BMJ Case Reports today and you can:

- Submit as many cases as you like

- Enjoy fast sympathetic peer review and rapid publication of accepted articles

- Access all the published articles

- Re-use any of the published material for personal use and teaching without further permission

For information on Institutional Fellowships contact consortiasales@bmjgroup.com

Visit casereports.bmj.com for more articles like this and to become a Fellow 